\title{
Medicine, A Pan-Historical, Pan-Cultural Science
}

\author{
Iris-Panagiota Efthymiou* and Vozikis A \\ Laboratory of Health Economics and Management, University of Piraeus, Greece
}

Submission: February 10, 2017; Published: March 09, 2017

*Corresponding author: Iris-Panagiota Efthymiou, Laboratory of Health Economics and Management, University of Piraeus, Karaoli \& Dimitriou St. 80, Pireas 185 34, Greece, Tel: +302104142280; Email: irisefthymiou@gmail.com

\begin{abstract}
Health is not just the lack of disease or disability, it is a human right. The pursue of health reveals our constant struggle that derives from our human nature; that is the battle against death. Health in the terms of wellbeing, from the ancient times, has been related with a sound mind, body and psyche. As such medicine lies in the heart of human effort not only for physical, mental, and social well-being but also to understand nature. In the face of this science philosophers, scholars, professionals, researchers, and not only, have been always joining forces in the name of its progress regardless their religion, culture, and geography; creating a unique pan-historical and pan-cultural science, nowadays moving on the path to become also a science free of geographical barriers.
\end{abstract}

Keywords: Global medicine; Medicine; Health; Health care; Ancient medicine; Trends

\section{Introduction}

Hopefully we are all well aware that health is not simply the lack of disease or disability, but can be defined as a condition of full physical, mental, and social well-being. Timeless is the tendency of humankind to combat disease, a reaction that stems from self-preservation instinct, and enjoy health and longevity. In the "heart" of health lies medicine; a science that, from the era of Hippocrates (and not only), among others father of medicine, unites people under a common goal.

Medicine is both a broad science and a personal art at the same time. From the magical invocations of the primitive man towards some higher force to its present time form of a systematic scientific methodology aimed to restore the balance between an individual's internal and external environment, medicine has been characterized, amongst others, by the constant observation of the various functions of the body and the mind as well as people's awe at disease. Just like with most scientific directions, the foundations of modern medical thought were established in ancient times, within the restless spirit of the Ancient Greek thought. Let's not forget that many terms used until today in medicine also derive from Greek words. eg. Cardiovascular from cardio (from Greek kardia/ $\alpha \rho \delta$ ió=heart) + vascular. Of course, integrated therapeutic systems were developed not only in
Greece, but within the framework of other great civilizations, and are still evolving until today with the contribution of the entire medical community.

\section{Medicine, a Science Greater than All of Us}

The history of medicine is pretty long and remarkable as since the dawn of humanity, there has had to be a way to cure the sick from all kinds of ailment or disease, and comfort a troubling body or mind. Inevitably when we talk about ancient medicine in particular, there are at least five countries to be mentioned, China, Egypt, Greece, India and Iran; the presentation is done alphabetically as to not comment on which country offered the most important contribution. A contribution not done only by men, as most thinks, but also from women.

Medicine is at least one scientific field where all humanity is united in the name of its progress; the mindset of the entire medical community could be characterized as set in the new step, the new discovery, the new piece of information. It surpasses sex, political borders and religious relations, although religious beliefs influence medical decisions and at times may conflict with medical care [1], as it is a body of knowledge that benefits all people. This science stands alone as the field that is in a constant state of progress, a field that always moves forward, 
and if the medical field sometimes looks in the past, it is to find answers based on previous knowledge. Current medicine is a one of a kind field were all mankind unites, medicinal researchers of all nationalities are cooperating with each other and new information are in constant flow.

In ancient times, the various traditional medicines of different countries may have shared similarities, as dealing with the same diseases, but at the same time were separated by fundamental philosophical differences. Each culture had its very own approach towards what illness is, how diagnosis and treatment should be done, its very own beliefs and points of view. Western medicine and Easter approach today, or to the untrained eye, seems different from each other, however if we take a look to the traditional medical systems of various countries (or at least of the five mentioned above) we will see the similarities in their holistic approach, the exchange of ideas will be revealed to us, and we could be astounded by the volume of communication between practitioners. After all, ideas and practices in the past traveled much more than we tend to believe today. In the past the scientists of Islam, for instance, got many ideas from Greece and India, they combined and evolved them, and now, modern medicine owes a lot to the work of Islam's doctors, that still applies.

Current examples vary from providing telemedicine services in conflict areas, to the case of Pharmacogenomics, the promising field of personalized treatment for patients suffering from many common diseases, and as action taken by initiative, mentioned by Mitropoulos K et al. [2], to disseminate the knowledge or the resources to individualize drug therapy globally [3-5].

\section{Conclusion}

Medicine has had a long history; it is a science evolving for many years and still is in a constant move forward. Of course there have been cases in the past where medicine has used to evolve findings of research that has been done under, to say at least, unclear situations; but these are just some isolated cases. However this element will be tackled in future work.

Medicine is not just a scientific field but the "idea" of a "higher purpose" that unites all under a common umbrella. People have been, and are still being collaborating leaving their differences on the side, focusing on the common ground, and now with the evolution of technology they are also breaking down the geographical barriers.

\section{References}

1. Koenig HG (2004) Religion, spirituality, and medicine: research findings and implications for clinical practice. South Med J 97(12): 1194-1200.

2. Mitropoulos K, Johnson L, Vozikis A, Patrinos GP (2011) Relevance of pharmacogenomics for developing countries in Europe. Drug metabol Drug Interact 26(4): 143-146.

3. Eftymiou- Egleton I (2016) Trends in Health Care. Xlibris, USA.

4. Porter D (1999) Health, civilization, and the state: a history of public health from ancient to modern times. Psychology Press, UK.

5. Zachariah R, Bienvenue B, Ayada L, Manzi M, Maalim A (2012) Practicing medicine without borders: tele-consultations and tele-mentoring for improving paediatric care in a conflict setting in Somalia? Trop Med Int Health 17(9): 1156-1162.

\section{Your next submission with Juniper Publishers will reach you the below assets}

- Quality Editorial service

- Swift Peer Review

- Reprints availability

- E-prints Service

- Manuscript Podcast for convenient understanding

- Global attainment for your research

- Manuscript accessibility in different formats

( Pdf, E-pub, Full Text, Audio)

- Unceasing customer service

Track the below URL for one-step submission https://juniperpublishers.com/online-submission.php 